Article

\title{
Refugees' Access to Housing and Residency in German Cities: Internal Border Regimes and Their Local Variations
}

\author{
Nihad El-Kayed * and Ulrike Hamann \\ Department of Diversity and Social Conflict, Humboldt University Berlin, 10099 Berlin, Germany; \\ E-Mails: n.el-kayed@hu-berlin.de (N.E.-K.), ulrike.hamann@sowi.hu-berlin.de (U.H.) \\ * Corresponding author
}

Submitted: 30 November 2017 | Accepted: 5 March 2018 | Published: 29 March 2018

\begin{abstract}
This article examines how state regulations, market barriers, racist discrimination as well as NGOs interact and create internal border regimes by enabling, as well as restricting, access to social and civil rights connected to housing and the freedom of movement and settlement for refugees. Our contribution builds on an analysis of federal and state regulations on housing for refugees who are either in the process of seeking asylum or have completed the process and have been granted an asylum status in Germany. The analysis aims to dissect the workings of these regulations in order to develop a detailed understanding of how these internal border regimes define barriers and access to social and civil rights. In addition to legal and regulatory barriers at the federal, state, and local levels, we identify several other barriers that affect if, how, and when refugees are able to enter local housing markets. We will examine these barriers based on an exemplary analysis of the situation in the cities of Berlin and Dresden, whereby we will apply concepts from border as well as citizenship studies to obtain a deeper understanding of the processes at hand. While contributions to the realm of border studies have so far mostly concentrated on national or EU borders, our approach follows recent literature that emphasises the need to analyse the workings of borders internal to nation-states but has so far not addressed local variations of the ways in which refugees are able to access their right to housing. In taking up this approach, we also stress the need to look at local dimensions of an increasing civic stratification of refugee rights, which past research has also conceptualised primarily on the national level. In both cities, we have collected administrative documents and conducted interviews with refugees, NGOs, and representatives from the local administration. Based on this material, we analyse the workings of administrative barriers at the state and local levels along with market barriers and discriminatory practices employed by landlords and housing companies at the local level. In most cases, these conditions restrict refugees' access to housing. We will contrast these obstacles with insight into the strategies pursued by refugees and volunteers in their efforts to find a place to live in the city.
\end{abstract}

\section{Keywords}

border studies; civic stratification; differential inclusion; Germany; housing; internal border regimes; refugees

\section{Issue}

This article is part of the issue "The Transformative Forces of Migration: Refugees and the Re-Configuration of Migration Societies", edited by Ulrike Hamann and Gökçe Yurdakul (Humboldt University of Berlin, Germany).

(C) 2018 by the authors; licensee Cogitatio (Lisbon, Portugal). This article is licensed under a Creative Commons Attribution 4.0 International License (CC BY).

\section{Introduction}

When refugees enter the territory of The Federal Republic of Germany and apply for asylum, they are confronted with a number of multi-layered regulations that affect their ability to reside in and move freely around the territory. This includes obligations to live and/or be present in specific municipalities and types of accommodation. We are interested in the ways in which these restrictions of civil rights related to housing and residency are struc- 
tured. In this article, we will focus on the transition process that refugees undergo from being obliged to live in state-organised forms of mass accommodation to the actual ability to rent their own apartment, and we will examine which factors affect this transition. In our analysis, we identify several layers of internal border regulations that create barriers and access to individual housing, which notably differ across federal states and municipalities. The length of time that refugees are kept waiting (Oldfield \& Greyling, 2015) in regard to housing thus depends, among other things, on the state and municipality to which they are allocated.

In connection with recent theoretical developments in the field of border and citizenship studies, we stress the potential to understand these processes as part of the multifaceted and complex workings of border regimes beyond and within nation-states. We find it useful to link to approaches that go beyond the usual interest of border studies in national borders and that understand the border as an epistemic angle as well as a research object. We find these approaches beneficial as they grasp the violence and exclusion that borders produce while also taking into consideration the imperfection and porousness of border regimes (Mezzadra \& Neilson, 2013). This expands the concept of border from a physical demarcation of a geographical entity, such as a nation-state, to issues of how states try to govern the mobility of people within their territory. The manner in which states try to regulate the residency of refugees before and after they enter the territory of a state is an obvious example of these complex workings of borders. In this article, we look at the issue of refugee housing, specifically the process by which refugees go from being housed in camps to having the right to move into individual housing. We consider this transition to be a crucial condition for refugees' arrival in society. In order to understand this process, we will analyse the methods of the state-which are often uneven - to regulate the housing of refugees, as well as their freedom of movement and settlement. We argue that the legal rights of refugees are undergoing increasing stratification, whereby elements such as a refugee's legal status and country of origin, as well as the different localities in a nation-state where refugees are placed, are emerging as particularly significant. While past research has already pointed to the increasing stratification of access to rights and practices on the national level (Kofman, 2005; Morris, 2003; Torres \& Waldinger, 2015), we seek to add to this debate by demonstrating the need to trace this stratification across multiple levels-national, federal state, local-and by showing how the resulting design of the system of (restricted) access is further affected by factors including local administrative practices, housing market actors, and civil society actors such as NGOs and refugees.

We will begin by presenting our theoretical approach and research methodology and proceed to discuss the regulations at different state levels. To demonstrate how these regulations play out at the local level, we will go from top to bottom in our analysis, starting at the federal level and moving on to the state and then local level in order to assess how they interlock. Due to this multilevel governance structure (García, 2006), the means by which these regulations can interlock at the local level are highly varied and complex. To illustrate this range, we will focus on two local examples, Berlin and Dresden, and show how these regulations interact with local conditions, such as differences in local administrative processes, the housing market, and discriminatory practices on the housing market. These internal borders stand in contrast to the strategies and perspectives of refugees and NGOs. The combination of all of these factors shapes refugees' ability to access individual accommodation.

\section{Theoretical Approach and Methodology}

\subsection{Autonomy of Migration, Differential Inclusion, and Civic Stratification}

Within the broad range of border regime studies (see Horvath, Amelina, \& Peters, 2017), most of the studies conducted to date have mainly looked at border spaces as sites of struggle, regulation, and exclusion, concentrating on the geographical border space of nation-states or focusing on the EU border (i.e., Donnan \& Wilson, 1999; Hess \& Kasparek, 2017; Transit Migration Forschungsgruppe, 2007). In this article we argue that there is a need to also look at local dimensions and variations of border regulations in order to understand how refugees are affected by such regulations after they have entered a national territory. In this regard, we refer to recent efforts that have been made to broaden the perspective on border processes in order to include analyses of how borders continue to operate internally, in the territory of a nation-state (see e.g., Lebuhn, 2013; Mezzadra \& Neilson, 2013). We see this development as especially fruitful for understanding the legal and practical situation of refugees and asylum seekers in terms of accessing housing, as this group of people is placed in a specific migration regime designed as an internal border zone, one that is characterised by mass accommodation camps, restrictions on movement, and residency requirements. We will follow this shift by applying the thesis of the multiplication of the border (Mezzadra \& Neilson, 2013, p. VI) to regional, local, and urban situations of bordering and by examining the mechanisms at the federal, state, and local level involved in achieving the differential inclusion of refugees.

Our theoretical approach is based in the field of critical migration studies, which criticises the "mechanistic or hydraulic" (Casas-Cortes et al., 2015) perspective on migration that considers mobility to be the sheer result of push-and-pull factors. In contrast, the autonomy of migration approach takes into account the fact that, despite strong and militarised attempts to regulate migration towards the EU, these regulations have not succeeded in turning Europe into a "Fortress Eu- 
rope", sealed off against migration. On the contrary, and as the long "summer of migration" (Kasparek \& Speer, 2015) demonstrated in 2015, people on the move interact with these attempts to regulate mobility, undermine them, and act within them. These interactions lead to a "complex system of limitations, differentiations, stratifications, and partial inclusions of migrant groups" (Bojadžijev \& Karakayali, 2007, p. 204, translation by the authors), resulting in a border regime that is not only repressive and exclusive, but also inclusive in a stratifying way, while continuously being challenged by the practices of migrants and constantly changing in order to keep up with them.

This interrelational aspect of power is central to Mezzadra and Neilson's (2013) approach to theorising the border in Border as a Method, in which they understand the border as a political space that multiplies into various other spaces and is both a geographically situated concept as well as one that stratifies society. This theorisation of the border is an "epistemological viewpoint that allows an acute critical analysis not only of how relations of domination, dispossession, and exploitation are being redefined presently, but also of the struggles that take shape around these changing relations" $(2013$, p. 18). If we define the border as a site of struggle in the context of migration regimes, we can identify the sites where the border has been multiplied within the geographical space of the nation-state and where migration regimes continue to operate, such as in the form of camps and other segregated housing sites for refugees. This "proliferation and heterogenisation of borders" (2013, p. 18), has led to various kinds of differential inclusion. The concept of differential inclusion, borrowed from feminist critical approaches, has been used, for example, in the analysis of migration regimes (Casas-Cortes et al., 2015, p. 79). It "draws attention to the effects of negotiations between governmental practices, sovereign gestures, the social relation of capital, and the subjective actions and desires of migrants" (2015, p. 79). For our research on the situation of refugees in the transition from being placed in camps and shelters to participating in the housing market, the concept of differential inclusion provides us with a broader view on the "tensions, encounters, and clashes between the practices and movements of migrants and the workings of the various apparatuses of governance and governmentality that target them" (Mezzadra \& Neilson, 2013, p. 165). This mirrors recent developments in the extensive literature on camps. Recent contributions to this literature have stressed that the camp is often not just a state of exception which strips camp residents of the right to have rights-as argued in influential analyses by Agamben and others (Agamben, 1998; Minca, 2015)-but frame the camp differently as a space of emerging new political subjectivities which can also open up limited access to citizenship dimensions (Maestri, 2017; Sigona, 2015). Our research, however, does not focus solely on the camp but on the possibilities and restrictions related to leaving the camp. Therefore, the political subjectivisation of refugees we are looking at here is shaped not only by the experience of the camp, but also by questions regarding access to housing outside of the camp and the kinds of barriers that must be overcome to achieve that access (e.g., related to local housing market specificities or discrimination). Literature on German housing markets, on the other hand, has only partly addressed the specific conditions that migrants face in the housing market (see e.g., Barwick, 2011; Faist \& Häußermann, 1996; Kiliç, 2008). The point where both fields overlap, the moment when refugees leave the camps and try to access the housing market, is, however, still a blank spot. Our study seeks to fill this gap.

The concept of the border as an epistemological lens, including the concept of differential inclusion, can be connected to discussions on the stratified access that different categories of migrants and non-citizens have to a number of rights. It is often argued that membership or access to rights and practices is increasingly detached from formal national citizenship status, resulting in forms of post- or denationalised membership forms based in globalisation processes such as human rights (Soysal, 1994) as well as in-often local-practices and actors that realise aspects of membership that divert from the concept of state membership (Sassen, 2005). While it is true that in many countries, social rights (rights to economic welfare) and civil rights (rights of individual freedom, cf. Marshall, 1950) in particular are not exclusive to formal citizens, such a perspective has been criticised for underestimating the continuing relevance of nation-states (Bloemraad, Korteweg, \& Yurdakul, 2008, pp. 165-166). Parts of this debate have furthermore focused-explicitly or implicitly-on resident aliens with a permanent resident status. Opening the perspective to migrants with less stable statuses, such as refugees, shows that the situation is much more complex and often enmeshed with border regulations (see Faist \& Häußermann, 1996). Lydia Morris (2003) argues that there is a need to analyse the "increasing diversity of 'outsider' status" (p. 79) by understanding "the qualifying conditions of access, and the nature of the interplay between domestic, transnational and supranational law" (p. 77). She proposes to use the term "civic stratification" to analyse partial membership as "a system of inequality based on the relationship between different categories of individuals and the state, and the rights thereby granted or denied" (p. 79). We use the term civic stratification particularly with regard to the legal differentiations that apply to asylum seekers, who are put in a number of categorisations (e.g., the stage of their asylum-seeking process or their country of origin). In this sense, civic stratification is part of the process of differential inclusion and contributes to the specific outcome of it. We thus understand the latter as a more encompassing notion in the sense that it focuses more specifically on the realisation of rights. Similar to border studies, studies on civic strati- 
fication focus mostly on national variations in civic rights (Morris, 2003; Torres \& Waldinger, 2015). We would like to add to this research by showing that there is a need to include regional and local variations of civic stratification, as access to rights and practices can be different for migrants with the same legal status depending on their location in a nation-state.

While there have been efforts to examine how citizenship rights and practices are shaped in different cities (see e.g., Varsanyi, 2006), these attempts have so far tended to neglect the role of internal border mechanisms on the local level (for a critique see e.g., Lebuhn, 2013) and their embeddedness in multilevel governance structures (see e.g., García, 2006). In most cases, literature on local or urban citizenship(s) tends to depict local forms of membership and participation as more inclusionary than national ones and to disregard exclusionary local processes (see e.g., Holston, 2008, for a critique see Purcell, 2006). We therefore argue that it is especially fruitful to focus on local dimensions of citizenship rights and practices with approaches of civic stratification, border regime studies, and differential inclusion to analyse how refugees access housing and show how heterogeneous processes of differential inclusion play out on the local level.

In the following, we would like to add to these discussions by analysing the local internal border regimes regarding housing, residency, and freedom of movement with which asylum seekers are confronted. In this vein, we will analyse civic stratifications regarding access to social and civil rights in interaction with administrative, market and civil society processes on the ground that produce complex situations of differential inclusion.

\subsection{Methods}

In this article we use empirical material from a study carried out between May and December 2016 which focused on the housing situation of female refugees in Berlin and Dresden (Foroutan, Hamann, El-Kayed, \& Jorek, 2017). We aim to compare the barriers that refugees with different legal statuses face when it comes to accessing housing rights in two different cities. Our comparison takes into consideration two dimensions that are significant within this context-legal status and locality. In pursuing our research question, we conducted semi-structured interviews with representatives from federal state and municipal administrations, with politicians as well as with representatives of NGOs, social workers, and volunteers who work in the field of housing for refugees. Furthermore, we interviewed 16 female refugees who were living in different types of camps, shelters, or apartments. These perspectives counter the administrative view while providing specific insight into the prospects of people with refugee status for housing and living in the city. For the purposes of this article, we combined three sets of data retrieved from the interviews with an analysis of administrative documents. The interviews with state officials provided administrative perspectives on how the housing of refugees should be organised in the respective city and gave us the chance to question state strategies. The other two sets of interview data - with NGOs and refugees-counter the administrative portrayal of refugee housing programs. NGOs represent another perspective, mostly that of German citizens who have the privilege of knowing the language and the local setting. NGO members lobby for refugees and are familiar with the practical outcomes of government regulations. The interviews with refugees provide the opportunity to question and control the information expressed by government actors and NGOs. However, as our article deals mostly with barriers that refugees face when looking for housing, we will mostly present findings based on our interviews with administrations and NGOs. At the same time, our analysis is based on our knowledge regarding the perspective of refugees, on which we have published more extensively in Foroutan et al. (2017).

\section{Federal Regulations}

The regulation of refugees in the Federal Republic of Germany is embedded in a multilevel system that includes laws and regulations at the EU level, the federal level, the federal state level, and the municipal level (Aumüller, Daphi, \& Biesenkamp, 2015; Schammann \& Kühn, 2016; Wendel, 2014). The laws and regulations from these various levels combine to affect the way refugees are housed in the asylum-seeking process and when and how refugees can enter the housing market. In the following section, we will discuss regulations on the German federal level that grant and restrict access to the right to housing and the right of free movement and settlement. These regulations exemplify the status of refugees as a specific category of migrants who are deliberately being held in unique situations of "waiting for the state" (Oldfield \& Greyling, 2015) by placing them in extended border zones manifested in both spatial and temporal dimensions.

While laws and regulations offer access to legal rights and a basic provision of social rights, they simultaneously erect internal temporal borders (Mezzadra \& Neilson, 2012). These regulations not only establish a particular legal position for asylum seekers and differentiate them from other categories of immigrants, denizens and citizens, but also create a wide range of differentiations among asylum seekers themselves as different regulations apply to specific subcategories of asylum seekers. The latter differentiation is the product of laws and regulations that establish the subcategorisation of asylum seekers and furthermore introduce tension between humanitarian and economic categories of "worthiness" that determine who can escape the border zone of waiting (earlier) and who cannot. Temporal border zones internal to nation-states are thus shaped by the inclusion and exclusion of certain groups of people to and from rights in multifaceted ways. 


\subsection{During the Asylum-Seeking Process}

When asylum seekers arrive in Germany, they are allocated to a specific federal member state through a distributional process based on the tax income of the federal member states as well as their population size-a process known as the 'Königsberger Schlüssel' ( $\$ 45$ AsylG). This mechanism handles the distribution along administrative rationalities while refugees themselves have little to no say in the matter of where they are placed (Wendel, 2014, p. 9). Asylum seekers are then housed in Erstaufnahmeeinrichtungen (EAE; 'initial accommodation facilities') where they must stay for up to six months ( $\$ 47$ AsylG). During the stay in such a facility, asylum seekers are usually subject to a 'residency requirement' (Residenzpflicht), which means that they are generally not allowed to leave the district (Bezirk) in which the local department of the Foreigner's Office (Ausländerbehörde) to which they have been assigned is located $(\S 55, \S 56$, $\S 57, \S 59$ a AsylG). Persons from countries that have been labelled 'safe countries of origin' ${ }^{1}$ even have an 'obligation to reside' (Wohnverpflichtung) in the EAE throughout the full duration of their asylum proceedings and are thus subject to the residency requirement during the entire process ( $\$ 47$ la AsylG). This keeps them in a space of "limbo" while they wait for the state to decide upon their application-a situation regarded by legal experts as a severe violation of basic civil rights (Pelzer \& Pichl, 2016, pp. 99-100). While they fall under this requirement, asylum seekers are only allowed to leave the district with permission from the Foreigner's Office. Violating the 'residency requirement' can lead to detention and a criminal record ( 599 II AsylG; §95 । Nr. 6a AufenthG; §95 । Nr. 7 AufenthG), and for some refugees from so-called 'safe countries of origin', even to a termination of their asylum application ( $\$ 33$ II, $\S 33$ III AsylG.). This requirement is considered disproportional and in contradiction to European Law by legal experts (Pelzer \& Pichl, 2016, p. 100). Furthermore, the 'residency requirement' can be reinstated after its termination and used as a punishment, for example, in cases where an asylum seeker has been convicted of a criminal act ( $\$ 59 \mathrm{~b}$ AsylG). The 'residency requirement' is therefore an extreme example of how refugees are held in designated border zones after their arrival on a nation-state's territory. The regulation restricts the freedom of movement and traps refugees in specific areas within the territory of the nation-statetemporarily and, in some cases, for the entire duration of stay-a situation that contradicts several international and European laws and regulations that establish the right of free movement for refugees (Pelzer \& Pichl, 2016, pp. 100-101).

From the EAE, asylum seekers are allocated to a specific municipality or district in the same federal state as the EAE in which they were first housed. Once again, asylum seekers have no say in the matter ( $\$ 50$ IV AsylG).
According to §53 I 1 AsylG asylum seekers should generally be housed in shared or mass accommodations in municipalities (Gemeinschaftsunterkünften; GU). This rule, however, is currently being interpreted differently across the federal states: some see it as an obligation to house asylum seekers in such GUs, while other states instead see no obstacle in this rule to house asylum seekers in apartments or other types of accommodation (Wendel, 2014, p. 11; Schammann \& Kühn, 2016). Many experts evaluate the legal situation to the effect that it is up to the regional and local administrations to decide how to accommodate asylum seekers (Wendel, 2014, p. 11). This is a first instance of leeway for differences in civic stratification across federal member states regarding the conditions of accommodation for refugees and their transition from state-organised housing to the housing market. In regard to several legal regulations, German federal law deliberately allows for differences in the internal border regimes in different federal states, and the implementation of these regimes can diverge further between municipalities in the same federal state. The federal law therefore co-creates-together with other administrative levels-"different (local) border regimes" that are the result of contradictory practices of the many different (institutional) actors on each level and conflicts of interests among them (Lebuhn, 2013, pp. 44-47). This multiplication and extension of the border can therefore not be adequately conceived as a coherent, strict border in a one-dimensional sense, but must be understood as multidimensional and uneven as it varies along a) government levels, b) geographical entities (federal states/regions/municipalities) in the same nation-state, and c) legal categorisations of migrants. Furthermore, it is shaped by local practices of administrative and civil society actors as well as refugees themselves, as we will show later on.

The regulations depicted above apply to refugees in the process of seeking asylum. In the next section we will focus on policies that apply to refugees once they have acquired an asylum status, and we will examine how these affect border arrangements and the situation of differential inclusion.

\subsection{Internal Borders after the Acquisition of an Asylum Status}

Since 2016, German federal law restricts the place of residence not only of persons in the asylum process, but also that of persons who have received asylum status and are therefore in possession of a residence permit. Prior to this date, recognised refugees could take up residence in any federal state or municipality in Germany. The newly introduced regulation of 'abode constraint' (Wohnsitzauflage) restricts the freedom of settlement and requires all refugees to take up residence in the federal state where his or her asylum procedure took place and to re-

\footnotetext{
${ }^{1}$ The countries currently defined as 'safe countries of origin' are: EU countries, Albania, Bosnia-Herzegovina, Ghana, Kosovo, Macedonia, Montenegro, Senegal, Serbia. (http://www.bamf.de/DE/Fluechtlingsschutz/Sonderverfahren/SichereHerkunftsstaaten/sichere-herkunftsstaaten-node.html)
} 
main there for three years. ${ }^{2}$ This regulation is, however, only partly a prolongation of the residency requirement discussed above, as the residency requirement prohibits refugees from physically leaving a certain area while the abode constraint prohibits refugees from taking up residence in a different federal state than the one to which he/she was allocated. The abode constraint does not, however, restrict a person from physically leaving the state temporarily (as the residency requirement does). The federal states have the power to introduce more detailed regulations that can require refugees to move either to or out of specific municipalities within a given federal state ( $\$ 12 a$ AufenthG), which opens up room for differences in civic stratification across federal states.

The official goal of the abode constraint is to "support sustainable integration" (\$12a I 1 AufenthG), and this wording ensures that the regulation is in line with European law which allows such restrictions for that specific reason, but not for others such as financial rationalities (Lehner \& Lippold, 2016; Thym, 2016, pp. 247-248). However, one of the abode constraint's major rationalities is, in fact, to distribute the financing of social welfare for refugees evenly across federal states and to facilitate regional and local administrative planning by making numbers more predictable (for a critique, see El-Kayed \& Hamann, 2016).

Generally, the abode constraint expires after three years, at which point refugees can choose their place of residence in Germany independently. There are, however, possibilities to be freed from the restriction prior to the end of this period, such as when a person's spouse and/or children live in a different federal state, or when a person or his/her spouse or children is employed, takes up vocational training or enrols at a university in a different state (§12a I 2 AufenthG; §12a V AufenthG; Thym, 2016, pp. 245-246). Thus, specifically those who are able to enter the labour market or the educational system acquire access to the basic right of free settlement while others do not.

While the residency requirement physically holds asylum seekers in areas that can be described as demarcated by temporal borders, the abode constraint creates an internal border by restricting housing market access for persons with asylum status. Enforcement of the abode constraint functions through its linkage to social welfare rights, as taking up residency outside of the allocated federal state results in refugees losing their entitlement to social welfare. This creates a tension between the access to social and civil rights, as accessing either one can result in the loss of the other. In sum, civic stratification and differential inclusion regarding the civil right to choose the place of residency are present even after an asylum seeker has been recognised as a refugee. Through the federal regulation of abode constraint, differential inclusion has become institutionalised on the federal level in the name of 'integration' and better governability of refugee migration at the lo- cal level. This development emphasises the need to examine this increasing civic stratification and differential inclusion across not only different migrant groups, legal statuses, or nation-states, but also different regions and localities.

\section{Federal State and Local Regulations}

As depicted above, German federal law creates leeway for federal states as well as municipalities when it comes to shaping refugees' access to housing. In the following, we will demonstrate how these federal regulations play out at the level of federal states and municipalities by taking a closer look at two municipalities in two federal states in Germany: Berlin, which is a city-state (and therefore shaped by a particular mix of federal state as well as municipal levels of government), and Dresden, a city in the federal state of Saxony. By describing the housing situation and the different barriers that exist for refugees in relation to entering the housing market in these two cities, we will illustrate the possible scope of local differences and will exemplify how these different regulations and practices on the ground affect refugees' access to the right to housing.

We selected Berlin and Dresden to account for different interpretations of federal law that currently exist on the federal state level. One major difference is that Berlin and Saxony have applied very different strategies for accommodating refugees in the past: Berlin had a rather liberal interpretation of federal law and implemented a possibility for asylum seekers to access private, individual housing (Wendel, 2014, p. 61). Saxony holds the opposing view and allows accommodation in private apartments only in the case of special humanitarian situations, such as a severe illness (Schammann \& Kühn, 2016, p. 12; Wendel, 2014, p. 63). Regulations on the federal state level, however, do not necessarily mean that there are indeed unified practices on the municipal level within a single state (Schammann \& Kühn, 2016, p. 12). This is also true for Saxony, where a range of accommodation concepts exists across municipalities. These differences in local regulations within a federal state sometimes originate in a deliberate attempt by municipal authorities to create a system that differs conceptually from that of the federal state. At other times, the wide range of accommodation concepts is a result of what many localities experienced as a state of exception during and after the height of refugee immigration to Germany in 2015. As a result of this extraordinary situation, many existing regulations and practices were abandoned (Schammann \& Kühn, 2016, pp. 11-14) and actors on the local level often switched to implementing 'whatever works'.

The administrative state of emergency led to bizarre situations: In Saxony, for example, some municipalities made long-term contracts for mass accommodation facilities in 2015, at a time when many refugees were arriving. This created a problem later on, as the numbers of

\footnotetext{
$\overline{2}$ This law was introduced for a limited time of three years and will remain in effect until August 2019 (§104 XIV AufenthG) if it is not renewed.
} 
refugees decreased afterwards. Now, cities like Dresden, which are housing some asylum seekers in apartments, which are under short-term contracts, are moving them out of the apartments and back into camps in order to save money.

\subsection{Berlin}

Berlin has had massive problems accommodating newly arrived refugees since the start of the main phase of refugee migration in 2015 . This administrative crisis has resulted in, among other things, long periods of waiting for registration and in the instalment of emergency accommodations in structures such as former office buildings, school gyms, exhibition or airport halls, and the like. These emergency facilities have been in use much longer than originally planned due to the city administration's problems in arranging accommodation in regular mass accommodation facilities or apartments. At the end of 2017, 5,000 refugees were still living in emergency shelters. ${ }^{3}$

Berlin is one of few federal states that allow refugees to seek their own apartment in the housing market after they have moved out of the EAE while still being in the asylum application process (Wendel, 2014). In 2016, the administration installed an information centre to support refugees in the process of finding an apartment. However, despite this administrative effort, in our interviews with refugees we often encountered a lack of knowledge or the presence of misinformation regarding the possibility to move out of the mass accommodation camps. It is therefore likely that this administrative information measure only had a limited impact.

Other measures taken by the Berlin administration included, for example, permission for refugees to spend $20 \%$ more on rent than what is possible for other social welfare recipients (Evangelisches Jugend- und Fürsorgewerk, 2016, p. 5). Another support measure consisted in a small number of flats provided by the municipal housing companies via a program called "Apartments for Refugees" (Wohnungen für Flüchtlinge, which provided 550 flats in 2016 and 270 in 2017). Due to the very limited number of units available, they were mainly used to house refugees who are considered to have a 'special need of protection', such as single-parent families and persons with disabilities or severe illnesses. But even for this group of refugees, this contingent was by no means sufficient. In our research we were furthermore confronted with statements that indicate that the municipal housing companies that provide these flats are less responsive to inquiries from refugees outside of this program. In this case, the provision of an insufficient housing contingent would have created the partial closing of a crucial affordable housing market sector for refugees. This border mechanism can again be conceived of as 'differential inclusion' as the politically marketable provision of an (inadequate) housing program specifically designed for refugees is connected to a limited general market ac- cess in return. Thus, the provision of a program framed as humanitarian co-creates a border that prevents equal housing market access and therefore access to the provision of a basic civil right.

\subsection{Dresden/Saxony}

After being accommodated in the EAE in Saxony, refugees are sent to municipal districts and cities where they are housed for the duration of their asylum proceedings. A number of housing concepts exist within the different municipalities, ranging from the predominant mass accommodation (e.g., in Bautzen) to housing in privately rented flats (e.g., in Leipzig). Due to the allocation mechanism in Saxony, $13.5 \%$ of all asylum seekers in Saxony are distributed to Dresden. In Dresden, it is generally not possible for asylum seekers who are still in the application process to enter the housing market and rent an apartment on their own. The predominant forms of housing in Dresden are therefore mass accommodations and shared flats, which are rented by the city. For these shared flats, there are regulations that also apply to mass accommodations (Landeshauptstadt Dresden, 2016, pp. 11-13). This means that in practice, six people share a three-bedroom flat with two people per room.

For refugees, entering the housing market in Dresden is-contrary to Berlin-only possible after the acquisition of an asylum status. Once a person has officially been recognised as an asylum seeker, a close cooperation with a large private housing company offers access to social housing apartments. However, according to our interview partners, the apartments that are allocated to refugees through this cooperation process are often in areas outside the city centre that have a reputation for being less welcoming to immigrants due to instances of openly communicated racism and racist violence.

So far, Saxony has not implemented an abode requirement that would oblige refugees to stay in the districts where their asylum proceedings took place. However, this type of regulation is being heavily discussed at the moment, as some politicians argue that more and more refugees are moving to urban centres in Saxony, such as Dresden and Leipzig, which would make it much more difficult for the federal state and municipal authorities to plan and administer their policies regarding refugees (Mitteldeutscher Rundfunk, 2017).

In addition to being shaped by these local administrative contexts, refugees' ability to access individual housing in these two cities is also affected by the local housing market, including incidents of discrimination, as we will show in the next section.

\section{Market Barriers and Barriers of Discrimination}

Over the course of the last decade, Berlin and Dresden have both developed from cities with a stagnant

\footnotetext{
${ }^{3}$ Sascha Langenbach, press spokesperson of the Berlin state agency for refugee matters (LAF) 11.12.2017, telephone interview.
} 
or shrinking housing market to cities with a new housing shortage that particularly affects low-income households (Schönig, Rink, Gardemin, \& Holm, 2017, p. 51). This urban housing crisis currently afflicting most of the larger cities in Germany is caused by several processes, such as the privatisation of parts of the communal housing stock, and it will not be solved in the near future, even though the cities are taking on new measures to mitigate this issue. There are indications that the urban housing crisis is having a disproportionate impact on migrants' chances to find housing. This is especially due to the withdrawal of the state from social housing programs that provided housing for low-income immigrant families, among others, and partially shielded them from discrimination in the private market (Bremer \& Gestring, 2004; see also Holm, Hamann, \& Kaltenborn, 2016).

Dresden used to have a large supply of vacant accommodation, but this supply has decreased significantly over the course of the last few years (Kofner, 2014). A significant number of private owners reject refugees as tenants, which is also true for the local non-profit housing companies that do not offer housing for refugees or social welfare recipients (Horvath et al., 2017, pp. 27-30, 50). The only major housing market actor who currently provides housing for refugees both during and after the asylum application process is a large private housing company that bought the municipal housing company WOBA in 2006. As part of the deal, the buyer agreed to guarantee a contingent of apartments which the city of Dresden can use for social housing (Mieterverein Dresden \& Umgebung e.V., 2016).

According to local NGOs, there is no considerable market in Dresden where refugees could find housing beyond this guaranteed contingent of social housing units. Different NGOs that support refugees in the search for housing in the city ascribe this fact to racist discriminatory practices among private owners and other housing companies in Dresden. The activities of these NGOs range from offering counselling to refugees in order to support their search for housing to providing financial guarantees for refugees to owners who doubt a foreigner's financial accountability. While some landlords cite concerns about refugees regarding language, communication, or social compatibility with other tenants, many of our interview partners relate these concerns to racist prejudices. A recent paired ethnic testing study on discrimination in the housing market in Saxony (Hummel, Krasowski, Midelia, \& Wetendorf, 2017) provides an empirical foundation for this observation of refugees and NGO activists. This study noted a significant number of cases of discrimination due to nationality, immigration status, and the lack of German language skills (2017, p. 25) by testing the reaction of landlords towards interested tenants with asylum status or their supporters, compared to German natives. In sum, the combination of a limited housing market and the discriminatory practices of landlords results in a situation where refugees are overwhelmingly dependent on the negotiated con- tingent of apartments that the city has agreed upon with one private housing company. According to local actors, the high prevalence of discrimination among landlords makes the housing market in Dresden extremely inaccessible for persons with refugee status.

In Berlin, access to the housing market for lowincome households has been dwindling since 2008. In 2016, urban sociologist Andrej Holm calculated a deficit of 275,000 affordable apartments for households on social welfare (Holm, 2016, pp. 34, 44-45, chart 27), a number that increases further if we include refugees who are still living in shelters and camps (cf. Landesamt für Flüchtlingsangelegenheiten, 2017). The situation for refugees in Berlin's housing market is extremely tough due to the extreme lack of affordable housing in general. Several additional obstacles prevent refugees from finding an apartment. One is the prevalence of incomplete or incorrect information among refugees about the possibility to move out of the camps after six months, which we encountered in our interviews. Furthermore, there are indications that social workers at camps and shelters were told by camp operators to not inform their clients about their housing rights. Besides this lack of correct information and the distribution of false information, there is a fraudulent shadow broker market where huge sums of money are demanded from refugees to secure an apartment, which in the end often turns out not to exist (Foroutan et al., 2017; Tagesspiegel, 2016).

The lack of affordable housing in the city is a major barrier to the Berlin housing market and one that also structurally enables possibilities for discrimination, as landlords and housing companies are able to choose among an increasing number of people applying for apartments. While there is a lack of standardised studies on Berlin, antidiscrimination counsellors have observed increasing discrimination in the Berlin housing market (Droste, KnorrSiedow, Dobrusskin, \& Domann, 2017, pp. 16, 54).

The two cities differ in their civil society attitude towards migration. As many parts of Berlin have a longer history of migration going back to labour migration from countries such as Turkey in the 1960s, the capital has fewer neighbourhoods which are dominated by racist street violence. Dresden has become a destination for significant numbers of migrants since 1989 , but in comparison to Berlin, it still has a low percentage of residents with a migration history (10.6\%). Furthermore, and concerning the difference in civil society attitude to migration, Dresden is the place of large, regular right-wing demonstrations by the movement known as PEGIDA (Patriotic Europeans Against the Islamisation of the Occident) since 2014. While thousands of racist protesters march through the inner city each Monday, People of Colour avoid the inner parts of the city. Refugees sent to reside in Dresden learn about this danger soon after arriving, as stated in interviews (Hamann, Karakayali, Höfler, Lambert, \& Meyer, 2017). Whether this situation is connected to landlords' reluctance to rent to refugees requires further investigation. 
The situation sketched out here demonstrates the state of differential inclusion that is constructed for refugees through the German refugee care system. Many newcomers, especially those in larger urban centres, are bound to an interim space that multiplies the nationstate border within urban spaces and keeps refugees in camps due to a combination of the lack of housing, the lack or mismanagement of information provided to refugees, and discrimination in the housing market. Each of these factors contributes to creating the situation of a deferred social arrival for refugees.

\section{Response Strategies and Refugees' Perspectives on Housing}

In our interviews with refugees-who mostly still lived in mass accommodation camps-all stressed the urgent desire to move out of the camp and into individual housing. Their wishes and expectations regarding housing are comparable to that of the average city dweller: priorities included the availability of infrastructures such as public transport, access to social and family networks, a wish for centrality and the desire not to be isolated in rural areas, and often a preference for mixed neighbourhoods in terms of spoken languages and migration histories. These expectations meet classic demands articulated in urban right-to-the-city-movements such as the right to centrality and difference (Holm, 2011; Lefebvre, 1968). These needs and wishes to centrality and difference face-as already depicted-legal restrictions, tight housing markets, and discrimination by housing market actors.

Despite this situation of a multiplied border produced by mechanisms rooted in the asylum system in Germany as well as market barriers such as the lack of affordability and discriminatory practices among landlords, some refugees find ways of gaining access to the urban housing markets. They often do so with the support of social networks or NGOs and volunteers. This state of affairs underlines the fact that borders are not strict, but always porous, and that their effectiveness is co-shaped by non-state actors. A considerable number of newly founded initiatives of volunteers support refugees in the search for housing. There are different models of support, from finding a room in a shared flat to providing help during the search process or providing a guarantee for a landlord. Each of these models seeks to engage with one or more of the aforementioned barriers created by the state, the market, or discrimination, but in doing so they face and, to some extent, also produce new problems. Across the board, these efforts are all highly timeand/or resource-intensive.

One example of such an initiative is a web-based matching platform that collects offers for rooms in shared flats and tries to match them with refugees who are searching for housing. The service is active in both cities, Berlin and Dresden, as well as in several other German cities. The process is intensively supported through counselling from local staff and volunteers. In our in- terviews with members of the organisation, they emphasised that while this program is a good fit for some refugees, it also has its downsides. A problem they frequently encounter is a mismatch between the needs and wants of the people offering a room and those of the refugees looking for a room. A common issue is that those who are willing to share a flat are often looking for a female or LGBTI person, whereas most refugees who are registered on the platform are single, most likely heterosexual men. Another issue that comes up is different ideas about privacy and living together. Those offering a room in their shared flat are often looking for someone who is interested in participating in everyday activities such as cooking meals together, etc., whereas many refugees are more often looking for a room where they can find rest and privacy. Besides conducting the matching process itself, the organisation is involved in counselling when such issues come up.

Another model that we encountered is the provision of support during the search for independent housing in a one-on-one counselling process provided by volunteers in NGOs as well as on the basis of individual volunteering not connected to NGOs. This approach pragmatically engages with the limited market situation and the discriminatory attitudes of landlords, especially in Dresden. The model takes into account that a search for housing in many urban centres in Germany requires German language skills, a high level of administrative skills, prompt reactions, and a certain type of knowledge about the social composition of a city's neighbourhoods. The volunteer's job includes communication with the landlord and neighbours, the time-consuming filling in of the needed documents or help with acquiring furniture and other household goods. It is a model that is especially timeconsuming for supporters.

This model of accompanying the search process on a one-on-one-basis was often described by NGOs and individuals as effective, not least because the organisation or individual volunteers provided a kind of symbolic guarantee for the landlord. Interviewees stated that they often had the impression that the fact that a potential tenant with refugee status is accompanied by a German citizen works as a signal that can help dissipate the reluctance of private owners to rent to refugees based on racist prejudices. In some instances, volunteers also provided financial guarantees for the apartment to overcome doubts by landlords. Some supporter groups were also renting apartments on their own in order to sublet them to refugee tenants. This model is one of the most pragmatic ways of dealing with the discriminatory reluctance of landlords to rent their apartments to refugees.

All models are rather small-scale and therefore cannot cover the actual need for housing compared to the number of refugees waiting in camps and shelters. They furthermore depend heavily on the capacities of volunteers to donate their time-and in some instances financial guarantees and resources. A high input of resources is therefore needed in order to reduce barriers 
that refugees encounter and to increase their access to the housing market. While these supportive structures can be crucial for a limited number of refugees, we would argue, however, that they are not able to change the dynamic of differential inclusion regarding refugees' access to housing in a fundamental way.

\section{Conclusions}

In this article we argued that refugees' ability to access civil and social rights related to housing and residency in Germany is affected by a multiplication of borders in urban and local spaces. We traced how the border regime regulates refugees' access to rights to housing from the federal to the local level as well as across different legal statuses during their process of seeking asylum. The transition from state-organised accommodation to housing market access is one of several transitions in different realms of civil and social rights that refugees undergo when changing between legal statuses during the asylum-seeking process (i.e., in the realm of the labour market or residence permit statuses). These transitions are, however, not linear, or always linked in a coherent way, and furthermore often organised along different rationalities - e.g., humanitarian vs. economic - that converge in some aspects and compete in others. This, in connection with regional and local differences, creates a system of vast differentiations-between different stages in the asylum-seeking process, federal states, regions, municipalities, as well as the categorisation of refugees according to their country of origin, their migration route, when they entered the territory, etc. This multiplied border regime therefore creates different "degrees of 'inside' and 'outside'" (see Mezzadra, 2009, p. 208), where the instances of control of refugees are carried out by a range of actors, both public, including authorities at the federal, state and local level, and private, such as gatekeeping actors in the housing market. On each level, we identified barriers to social and civil rights, such as the free choice of housing, that specifically apply to different types of asylum status and that vary not only from state to state but also across municipalities within the same state. The range of variation leads to an unequal treatment of refugees who hold the same legal status in different federal German states and cities. These internal local border regimes are marked by tensions between social and civil rights-e.g., when the provision of social welfare to refugees is linked to restrictions on their freedom of movement and settlement.

The right to free settlement is affected by a range of restrictive regulations, challenging market conditions, and discriminatory housing market actors that make it extremely difficult for refugees to find housing. This is particularly the case in urban centres, where many vulnerable and low-income groups are being shut out of the housing market.

Our findings point to the need for more systematic and encompassing studies on local variations of border regimes, including which factors influence these variations. Such an approach would also require more systematic research on the rationalities, strategies, and processes in administrations and of housing companies and landlords as well as on the strategies of resistance and circumvention by refugees and supportive civil society structures.

\section{Acknowledgements}

The research behind this article took place in the context of the Research-Intervention-Cluster on Flight and Solidarities at the Berlin Institute for Empirical Integration and Migration Research (Humboldt-Universität) which was funded by the Federal Government's Commissioner for Migration, Refugees and Integration. We thank all members of the cluster for fruitful discussions and questions, especially Susanna Jorek, Nassim Mehran, and Jinan Abi Jumaa. We thank Leoni Keskinkiliç for her careful editing and Diana Aurisch for proofreading.

\section{Conflict of Interests}

The authors declare no conflict of interests.

\section{References}

Agamben, G. (1998). Homo Sacer: Sovereign power and bare life. Stanford: Stanford University Press.

AsylG. (2008). Asylgesetz in der Fassung der Bekanntmachung vom 2. September 2008 (BGBI. I S. 1798), das zuletzt durch Artikel 2 des Gesetzes vom 20. Juli 2017 (BGBI. I S. 2780) geändert worden ist. Berlin, Germany: Government.

AufenthG. (2008). Aufenthaltsgesetz in der Fassung der Bekanntmachung vom 25. Februar 2008 (BGBI. I S. 162), das zuletzt durch Artikel 10 Absatz 4 des Gesetzes vom 30. Oktober 2017 (BGBI. I S. 3618) geändert worden ist. Berlin, Germany: Government.

Aumüller, J., Daphi, P., \& Biesenkamp, C. (2015). Die Aufnahme von Flüchtlingen in den Bundesländern und Kommunen. Behördliche Praxis und zivilgesellschaftliches Engagement. Stuttgart: Robert Bosch Stiftung.

Barwick, C. (2011): Draußen vor der Tür. Exklusion auf dem Berliner Wohnungsmarkt. WZB Mitteilungen, 134, 13-15.

Bloemraad, I., Korteweg, A., \& Yurdakul, G. (2008): Citizenship and immigration: Multiculturalism, assimilation, and challenges to the nation-state. Annual Review of Sociology, 34, 153-179.

Bojadžijev, M., \& Karakayali, S. (2007). Autonomie der Migration. 10 Thesen zu einer Methode. In Transit Migration Forschungsgruppe (Ed.), Turbulente Ränder: Neue Perspektiven auf Migration an den Grenzen Europas (pp. 203-209). Bielefeld: transcript.

Bremer, P., \& Gestring, N. (2004). Migranten-ausgegrenzt? In H. Häußermann, M. Kronauer, \& W. 
Siebel (Eds.), An den Rändern der Städte. Armut und Ausgrenzung (pp. 258-285). Frankfurt am Main: Suhrkamp.

Casas-Cortes, M., Cobarrubias, S., Garelli, G., Grappi, G., Heller, C., Hess, S., . . . Tazzioli, M. (2015). New keywords: Migration and borders. Cultural Studies, 29(1), 55-87.

Donnan, H., \& Wilson, T. M. (1999). Borders. Frontiers of identity, nation and state. Oxford: Berg.

Droste, C., Knorr-Siedow, T., Dobrusskin, J., \& Domann, V. (2017). Diskriminierung auf dem Wohnungsmarkt: Interventionsmöglichkeiten in Berlin (Gutachten). Retrieved from https://www.berlin.de/ sen/lads/beratung/diskriminierung/wohnungsmarkt /artikel.566259.php

El-Kayed, N., \& Hamann, U. (2016): Wohnsitzauflage fördert nicht die Integration. Retrieved from https:// mediendienst-integration.de/artikel/kritik-wohnsitz auflage-und-zuzugssperre-fuer-fluechtlinge-am-bei spiel-von-tuerken-und-spaetaussiedle.html

Evangelisches Jugend- und Fürsorgewerk. (2016). Häufig gestellte Fragen und Antworten zur Vermietung von Wohnraum an Asy/suchende. Retrieved from https:// www.ejf.de/fileadmin/user_upload/pics-einrichtungen /fluechtlingsarbeit/Fluechtlingsberatung/Infoblatt_ fuer_Vermieter_Mai2016.pdf

Faist, T., \& Häußermann, H. (1996): Immigration, social citizenship and housing in Germany. International Journal for Urban and Regional Research, 25(4), 439-459.

Foroutan, N., Hamann, U., El-Kayed, N., \& Jorek, S. (2017). Zwischen Lager und Mietvertrag-Wohnunterbringung von geflüchteten Frauen in Berlin und Dresden. Berlin: Berliner Institut für empirische Integrationsund Migrationsforschung

García, M. (2006). Citizenship practices and urban governance in European cities. Urban Studies, 43(4), 745-765.

Hamann, U., Karakayali, S., Höfler, L., Lambert, L., \& Meyer, L. (2017). Pionierinnen der Willkommenskultur. Pionierinnen der Willkommensgesellschaft. Strukturen und Motive des Engagements für Geflüchtete. Berliner Institut für empirische Integrations- und Migrationsforschung (BIM)

Hess, S., \& Kasparek, B. (2017). Under control? Or border (as) conflict: Reflections on the European border regime. Social Inclusion, 5(3), 58-68.

Holm, A. (2011). Das Recht auf die Stadt. Blätter für deutsche und internationale Politik, 89-97.

Holm, A. (2016). Sozialer Wohnraumversorgungsbedarf in Berlin. Berlin: Die Linke.

Holm, A., Hamann, U., \& Kaltenborn, A. (2016). Die Legende vom Sozialen Wohnungsbau. Berlin: Berliner Hefte zu Geschichte und Gegenwart der Stadt.

Holston, J. (2008). Insurgent citizenship. Disjunctions of democracy and modernity in Brazil. Princeton: Princeton University Press.

Horvath, K., Amelina, A., \& Peters, K. (2017). Re-thinking the politics of migration. On the uses and challenges of regime perspectives for migration research. Migration Studies, 5(3), 301-314.

Hummel, S., Krasowski, B., Midelia, S., \& Wetendorf, J. (2017). Rassistische Diskriminierung auf dem sächsischen Wohnungsmarkt. Situationsbeschreibung und Handlungsempfehlungen. Leipzig: Antidiskriminierungsbüro Sachsen e.V.

Kasparek, B., \& Speer, M. (2015). Of Hope. Ungarn und der lange Sommer der Migration. Retrieved from bordermonitoring.eu/ungarn/2015/09/of-hope

Kiliç, E. (2008). Diskriminierung von Migranten bei der Wohnungssuche-Eine Untersuchung in Berlin. Diplomarbeit im Fachbereich Sozialwissenschaften an der Humboldt-Universität zu Berlin.

Kofman, E. (2005). Citizenship, migration and the reassertion of national identity. Citizenship Studies, 9(5), 453-467.

Kofner, S. (2014). Anspannung am Dresdner Wohnungsmarkt: Handlungsmöglichkeiten der kommunalen Wohnungspolitik (Gutachten im Auftrag des Mietervereins Dresden). Dresden: Mieterverein Dresden.

Landesamt für Flüchtlingsangelegenheiten. (2017, November 1). Berlin: EASY-Zugangsstatistik. Retrieved from https://www.berlin.de/laf/wohnen/all gemeine-informationen/aktuelle-unterbringungszah len/artikel.630901.php

Landeshauptstadt Dresden. (2016). Fachplan Asyl 2014 bis 2016. Dresden: Landeshauptstadt Dresden. Retrieved from https://www.dresden.de/media/pdf/ presseamt/Fachplan-Asyl-2014-2016.pdf

Lebuhn, H. (2013). Local border practices and urban citizenship in Europe. City, 17(1), 37-51.

Lefebvre, H. (1968). Le droit à la ville. Paris: Anthropos.

Lehner, R., \& Lippold, A. (2016). Wohnsitzauflagen für anerkannte Flüchtlinge und subsidiär Schutzberechtigte: Was lässt das (Europa-)Recht zu? Zeitschrift für Ausländerrecht und Ausländerpolitik, 36(3), 81-89.

Maestri, G. (2017). Struggles and ambiguities over political subjectivities in the camp: Roma camp dwellers between neoliberal and urban citizenship in Italy. Citizenship Studies, 21(6), 640-656.

Marshall, T. H. (1950). Citizenship and social class and other essays. Cambridge: Cambridge University Press.

Mezzadra, S. (2009). Bürger und Untertanen. Die postkoIoniale Herausforderung der Migration in Europa. In S. Hess, J. Binder, \& J. Moser (2009), No integration?!: Kulturwissenschaftliche Beiträge zur Integrationsdebatte in Europa (pp. 207-223). Bielefeld: transcript Verlag.

Mezzadra, S., \& Neilson, B. (2012). Between inclusion and exclusion: On the topology of global space and borders. Theory Culture \& Society, 29(4/5), 58-75.

Mezzadra, S., \& Neilson, B. (2013). Border as method, or, the multiplication of labor. Durkheim: Duke University Press.

Mieterverein Dresden, \& Umgebung e.V. (2016, March 8). 
10 Jahre nach dem WOBA-Verkauf-Wie sieht es aus im "Mieterparadies". Retrieved from http://www. mieterverein-dresden.de/news-ansicht/article/3417 8-10-jahre-nach-dem-woba-verkauf-wie-sieht-es-aus -im-mieterparadies.html?cHash=4208699880bfd669 04b652844625a69b

Minca, C. (2015): Geographies of the camp. Political Geography, 49, 74-83.

Mitteldeutscher Rundfunk. (2017, October 12). Landesregierung über Wohnsitzauflage für Flüchtlinge einig. Retrieved from https://www.mdr.de/sachsen/ landesregierung-ueber-wohnsitzauflage-fuer-fluecht linge-einig-100.html

Morris, L. (2003). Managing contradictions: Civic stratification and migrants' rights. International Migration Review, 37(1), 74-100.

Oldfield, S., \& Greyling, S. (2015). Waiting for the state. A politics of housing in South Africa. Environment and Planning A, 47, 1100-1112.

Pelzer, M., \& Pichl, M. (2016). Wohnsitzauflage und Residenzpflicht: aktuelle Einschränkungen der Freizügigkeit von Flüchtlingen. Zeitschrift für Ausländerrecht und Ausländerpolitik, 3(36), 96-101.

Purcell, M. (2006). Urban democracy and the local trap. Urban Studies, 43(11), 1921-1941.

Sassen, S. (2005). The repositioning of citizenship and alienage: Emergent subjects and spaces for politics. Globalizations, 2(1), 79-94.

Schammann, H., \& Kühn, B. (2016). Kommunale Flüchtlingspolitik in Deutschland. Bonn: FriederichEbert-Stiftung.

Schönig, B., Rink, D., Gardemin, D., \& Holm, A. (2017). Paradigmenwechsel in der kommunalen Wohnungs- politik? Variationen kommunalisierter Wohnungspolitik im transformierten Wohlfahrtsstaat. In M. Barbehön \& S. Münch (Eds.), Variationen des StädtischenVariationen lokaler Politik, Stadtforschung aktuell (pp. 25-62).

Sigona, N. (2015). Campzenship: Reimagining the camp as a social and political space. Citizenship Studies, 19(1), 1-15.

Soysal, Y. (1994). Limits of citizenship. Migrants and postnational membership in Europe. Chicago: The University of Chicago Press.

Tagesspiegel (2016). Falsche Vermittler kassieren bei Flüchtlingen ab. Retrieved from http://www. tagesspiegel.de/berlin/wohnungen-in-berlin-vorge taeuscht-falsche-vermittler-kassieren-bei-fluechtlin gen-ab/13681918.html

Thym, D. (2016). Integration kraft Gesetzes? Grenzen und Inhalte des "Integrationsgesetzes" des Bundes. Zeitschrift Für Ausländerrecht Und Ausländerpolitik, 36(8), 241-251.

Torres, J. M. \& Waldinger, R. (2015). Civic stratification and the exclusion of undocumented immigrants from cross-border health care. Journal of Health and Social Behavior, 56(4), 438-459.

Transit Migration Forschungsgruppe. (Ed.). (2007). Turbulente Ränder. Neue Perspektiven auf Migration an den Grenzen Europas. Bielefeld: Transcript.

Varsanyi, M. W. (2006). Interrogating "urban citizenship" vis-à-vis undocumented migration. Citizenship Studies, 10(2), 229-249.

Wendel, K. (2014). Unterbringung von Flüchtlingen in Deutschland: Regelungen und Praxis der Bundesländer im Vergleich. Frankfurt am Main: Pro Asyl.

\section{About the Authors}
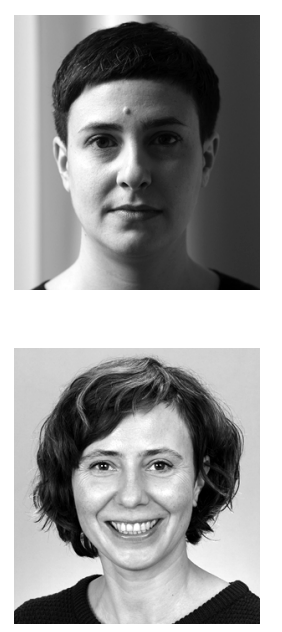

Nihad El-Kayed is a Research Associate at the Department of Diversity and Social Conflict at the Institute of Social Sciences and the Berlin Institute for Empirical Integration and Migration Research (BIM) at Humboldt University Berlin. Her research interests include citizenship and migration, political participation, neighbourhood research, social networks, social capital as well as sport and migration. She currently conducts a research project on "Welcoming Neighbourhoods-conditions of social cohesion in super-diverse communities" (funded by the German Federal Ministry of Education and Research)together with Ulrike Hamann.

Ulrike Hamann (Humboldt University Berlin) is a Research Associate at the Department of Diversity and Social Conflict at the Institute for Social Sciences and at the Berlin Institute for Empirical Integration and Migration Research (BIM). She holds a PhD from Goethe University in Frankfurt/Main in Postcolonial Studies. Her research focuses on questions surrounding migration, racism, housing and urban neighbourhoods. She is also an activist for housing rights. In a current research project, she studies conditions for social cohesion and conviviality in different neighbourhoods, varying in terms of socio-economic status and diversity, together with Nihad El-Kayed. 